\title{
ANTIGEN NON STRUKTURAL 1 (NS1) SEBAGAI MARKER SUSPEK INFEKSI DENGUE
}

\author{
Protein 1 Nonstructural Antigen (Ns1) As The Marker To Dengue Infected Suspect \\ Budi Santosa ${ }^{1}$, Herlisa Anggraini ${ }^{1}$, Arista Budi Fristiani ${ }^{1}$ \\ ${ }^{1}$ Program Studi Magister Sains Laboratorium Medis Universitas Muhammadiyah \\ Semarang
}

Koresponden: budisantosa@unimus.ac.id

\begin{abstract}
Dengue infection is considered as global health problem. The rate of the infection keeps on rising every year. The fatality rate due to dengue infection is categorized as high, especially the death caused by delayed healthcare. Laboratory checks up is very important to early diagnose the dengue suspect. Nonstructural protein 1 antigen (NS1) is considered to be sensitive as it specifically reacts to the existence of the dengue virus at the early stage of the infection (suspect). This research was aimed to find out the role of NS1 on suspected dengue patients. This research employed a descriptive approach or dengue suspected patients. The marker of dengue virus was obtained through medical records about the period of fever and the result of rumpel leed (RL) or tourniquet test from Roemani Hospital found the NS1 result from the laboratory checkup. The research finding showed that among 30 patients, 14 patients (46,6\%) were the dengue suspects with $0-2$ days fever, 3 RL positive (10\%) and $5 \mathrm{NS1}$ positives (16,6\%). 15 patients (50\%) with 3-4 days of fever, 1 RL positive (3,3\%) and 1 NS1 positive (3,3\%). Also 1 patient with 5-7 days of fever and NS1 negative. Conclusions, not all dengue suspects in Roemani Hospital get positive NS1. 16.6\% in fever symptoms 0-2 days, 3.3\% in fever symptoms 24 days, and 0\% in fever symptoms 5-7 days.
\end{abstract}

Keywords: NS1, dengue suspect

\section{ABSTRAK}

Infeksi dengue masih merupakan masalah kesehatan global. Angka insidensi dari tahun ke tahun belum mengalami penurunan. Angka kematian dari penderita cukup tinggi dan salah satu sebabnya adalah keterlambatan dalam penanganan penderita. Pemeriksaan laboratorium sangat dibutuhkan dalam menegakkan diagnosis dini penderita suspek dengue. Antigen non struktural 1 (NS1) dianggap sensitif dan spesifik yang dapat bereaksi dengan virus dengue sehingga dapat mendeteksi keberadaan virus ini pada awal infeksi (suspek). Tujuan dari penelitian ini adalah untuk mengetahui gambaran hasil NS1 pada penderita suspek dengue. Penelitian ini menggunakan pendekatan deskriptif dari pasien yang diduga terinfeksi virus dengue. Tanda-tanda virus dengue diperoleh dari catatan medis yang berupa masa demam dan hasil rumple leed (RL) dari RS Roemani, hasil NS1 diperoleh dari pemeriksaan laboratorium. Hasil penelitian menunjukkan dari 30 pasien yang suspek dengue dengan gejala demam 0-2 hari terdapat 14 orang $(46,6 \%)$, RL positif 3 orang (10\%), NS1 positif 5 orang (16,6\%). Gejala demam 3-4 hari terdapat 15 orang $(50 \%)$, 1orang RL positif $(3,3 \%)$ dan 1orang NS1 positif 3,3\%). Gejala demam 5-7 hari terdapat 1 orang $(3,3 \%)$ dengan hasil NS1 negatif. Simpulan bahwa tidak semua 
suspek dengue di RS Roemani didapatkan NS1 positif, 16,6\% pada gejala demam 0-2 hari, 3,3\% pada gejala demam 2-4 hari, dan 0\% pada gejala demam 5-7 hari.

Kata kunci: NS1 suspek dengue

\section{PENDAHULUAN}

Penyakit demam berdarah masih menjadi masalah global, hampir 390 juta orang terinfeksi setiap tahunnya. (Kemenkes RI, 2017). insidensi penyakit dengue dari tahun ke tahun cukup tinggi. Infeksi dengue banyak ditemukan di daerah tropis maupun sub tropis dan kebanyakan di wilayah perkotaan termasuk yang ada di Indonesia. Pada tahun 2015 angka kejadian di Indonesia sebanyak 21.092.(Dinkesprov. Jawa Timur,2017). Jumlah kasus DBD pada tahun 2017 sebanyak 68.407 dengan jumlah kasus meninggal sebanyak 493 orang dan IR 26,12 per 100.000 penduduk, jika dibandingkan dengan tahun 2016 mengalami penurunan. Pada tahun 2016 terdapat kasus sebanyak 204.171 dan IR 78,85 per 100.000 penduduk. ${ }^{1}$ Dari tahun 2008 sampai 2017 , jumlah kasus tertinggi di tahun 2016. Angka kematian atau case fatality rate (CFR) diatas $1 \%$ di provinsi Gorontalo $(2,18 \%)$, Sulawesi Utara (1,55\%, Sulawesi Tenggara $(1,47 \%)$ dan angka diatas $1 \%$ termasuk kategori tinggi). . (Kemenkes RI, 2017).

Virus dengue sebagai agen dari penyakit Demam Berdarah Dengue (DBD) masuk dalam family Flaviridae dan genus Flavivirus yang terdiri dari 4 serotipe yaitu Den-1, Den-2, Den-3 dan Den-4. Nyamuk Aedes aegypti dan Aedes albopictus merupakan vektor penularan virus dengue melalui gigitannya. ${ }^{3}$ banyaknya serotype inilah menjadi salah satu sebab hingga saat ini infesi dengue belum ditemukan vaksinnya.

Gejala klinis sejak infeksi dimulai dengan tanpa gejala, sampai demam dengue hingga demam berdarah. Demem tinggi bisa dijumpai dari hari kedua sampai hari ketujuh. Manifestasi klinis seringkali mirip dengan infeksi lain sehingga banyak kejadian penderita yang terlambat dalam penanganan. Pemeriksaan laboratorium menjadi penting dalam menegakkan diagnosis. Banyak parameter laboratorium yang bisa digunakan misalnya uji tourniquet, pemeriksaan jumlah trombosit, uji kebocoran plasma, imunoglobulin, dan antigen non structural 1 (NS1). Derajat keparahan DBD meliputi derajat I yang ditandai dengan demam disertai petechia positif, derajat II yang tandanya seperti derajat I disertai perdarahan spontan di kulit, derajat III ditandai dengan nadi cepat dan lemah, hipotensi, sianosis. Derajat IV ditandai dengan syok berat. (Hadinegoro et al, 2001; Numinha et al, 2012)

Berdasarkan mekanisme respon imun, kadar antibodi yaitu imunoglobulin $M$ akan meningkat dan dapat dideteksi pada hari ke-4 atau ke-5. (Rubens CLJ et al,2012; Trisnadewi NL et al, 2016). Pada suspek dengue IgM belum terbentuk, sehingga pemeriksaan keberadaan virus menjadi penting untuk diketahui. Salah satu parameter laboratorium yang dapat digunakan untuk mengetahui tahap awal infeksi adalah NS1, karena bisa mendeteksi keberadaan antigen dengue. (Mariko MR et al, 2014). Infeksi dengue menunjukkan adanya perbedaan gejala klinis akibat perbedan mekanisme patofisiologis. .(Chandra A, 2010). Variasi gejala klinis yang tidak spesifik dan ada kemiripan gejala yang ditimbulkannya dengan infeksi lain, maka perlu diketahui seberapa besar suspek dengue yang positif NS1 sebagai diagnosis pasti infeksi dengue. Pemeriksaan NS1 dapat mendeteksi bagian tubuh dari virus dengue sehingga tidak perlu menunggu respon tubuh 
terhadap infeksi virus. Oleh karena itu pemeriksaan ini paling baik dilakukan pada saat hari ke 0 mulai gejala panas muncul. Pada saat ini jumlah trombosit belum mengalami penurunan, IgM belum bisa dideteksi. Nilai sensitivitas dan spesifisitas cukup tinggi, sehingga jika hasil NS1 positif adalah benar-benar terjadi pada orang yang terinfeksi virus dengue, sebaliknya jika NS1 negatif adalah benar-benar terjadi ada orang yang tidak terinfeksi dengue.(Peeling et al, 2010)

\section{METODE}

Pada penelitian ini menggunakan jenis deskriptif yang dilakukan pada pasien suspek infeksi dengue di RS Roemani Semarang dengan melihat gejala klinik di awal infeksi berdasarkan catatan medis. Populasi dalam penelitian ini adalah semua pasien yang mengalami suspek infeksi dengue yang memeriksakan diri di RS Roemani Semarang. Sampel dalam penelitian ini adalah pasien suspek infeksi dengue berdasarkan gejala klinis dan cacatan medis yang memenuhi kriteria inklusi. Besar sampel sebanyak 30 orang yang diambil secara consequtive sampling. Pemeriksaan laboratorium dengan marker NS1 rapid dengan prinsip NS1 antigen yang terdapat di dalam serum/plasma akan bereaksi dengan anti dengue NS1 yang terdapat pada strip reagen sehingga membentuk komplek antigen antibodi yang melewati membran secara kromatografi menuju daerah tes yang dilapisi antigen spesifik virus dengue membentuk komplek antibodi-antigenantibodi yang membentuk garis sebagai tanda positif. Hasil positif maupun negatif dikelompokkam berdasarkan suspek infeksi dengue. Data dianalisis dan disajikan secara deskriptif menggunakan tabel.

\section{Langkah-langkah penelitian}

1. Pengambilan dan Penyimpanan sampel

Sampel yang digunakan pada pemeriksaan ini adalah Serum yang diambil dengan cara:

a) Darah vena dikumpulkan kedalam tabung reaksi (TIDAK mengandung antikoagulan seperti heparin, EDTA dan sodium citrate),

b) Didiamkan selama 30 menit hingga darah membeku dan kemudian dilakukan sentrifuge dengan kecepatan 1500-2000 rpm selama 15-20 menit hingga didapatkan sampel serum.

\section{Prosedur Pengujian NS1}

a) Reagen dan sampel diadaptasi terlebih dahulu pada suhu ruang.

b) Kantong tes dibuka dan diletakkan ditempat bersih, kering dan datar

c) Dengan menggunakan disposable dropper, ditambahkan 3 tetes sampel kedalam sumur (well) sampel bertanda (S)

d) Jika tes berjalan dengan baik, akan terlihat pergerakan warna ungu sepanjang jendela hasil menuju kebagian tengah tes

e) Interpretasikan hasil setelah 15-20 menit. Sebaiknya tidak membaca hasil setelah 20 menit karena dapat meberikan hasil palsu.

f) Hasil positip akan tetap setelah 20 menit. Walaupun demikian, untuk mencegah kesalahan hasil, jangan baca hasil setelah 20 menit. 


\section{Interpretasi Hasil}

a) Hasil Negatip: Jika hanya terbentuk garis pada area garis kontrol $(\mathrm{C})$

b) Hasil Positip: Jika terbentuk garis pada area garis (T) dan (C).

c) Hasil Invalid: jika tidak terbentuk garis pada area garis kontrol (C).

d) Untuk hasil Invalid dilakukan tes ulang.

\section{HASIL}

Berdasarkan data yang terdapat pada catatan medis dapat dikelompokkan berdasarkan definisi suspek infeksi dengue yaitu demam tinggi mendadak selama 2-7 hari tanpa sebab yang jelas dan rumple leed positif sebagai manifestasi perdarahan. Marker NS1 diperiksa dengan rapid test yang hasilnya dinyatakan positif dan negatif. Tabel 1 adalah hasil deskriptif suspek infeksi dengue dengan marker NS1.

Berdasarkan hasil penelitian yang sesuai tabel pada 1, marker NS1 positif paling tinggi yaitu $16,6 \%$ terjadi pada suspek yang mengalami demam pada kisaran 0-2 hari disertai hasil rumple leed positif, akan tetapi $30 \%$ pada periode demam tersebut hasil NS1 nya negatif. Hasil NS1 negatif hampir semua terjadi pada suspek infeksi dengue setelah melebihi dua hari meskipun ada 1 yang positif disertai juga rumple leed positif pada demam hari ke 3-4.

\section{PEMBAHASAN}

Karakteristik demam dengue dideskripsikan sebagai demam tinggi yang disertai sakit kepala, nyeri di belakang mata, nyeri otot dan sendi, muntah . Tidak semua orang yang terinfeksi memiliki gejala yang sama dan sulit digambarkan berdasarkan serotipenya ${ }^{11}$ bahkan gejala tersebut bisa terjadi pada penyakit yang lain.
.(Perdigão AC et al, 2016). Meskipun demikian, hasil NS1 positif diyakini terjadi pada penderita yang betul-betul terinfeksi dan negatif terjadi pada orang yang betul-betul negatif, hal ini disebabkan karena NS1 adalah marker infeksi dengue yang memiliki sensitivitas dan spesifisitas tinggi yaitu $97,4 \%$ dan 93,7\%.(Paranavitane SA et al, 2014) Menurut penelitian Paranavitana SA, 2014 bahwa hasil positif NS1 dikaitkan dengan risiko lebih tinggi terkena demam berdarah berat dan bisa digunakan untuk prognosis pada masa perawatan demam berdarah. Dalam penelitian ini metoda yang digunakan untuk pemeriksaan NS1 adalah strip kromatografi yang hanya dapat mendeteksi secara kualitatif, dan perlu konfirmasi dengan metode NS1 kuantitatif, serta perlu dibandingkan dengan metoda yang lain seperti ELISA. .(Ambrose JH et al, 2017)

Pada masa demam melebihi 2 hari, sebagian besar hasil NS1 negatif, hal ini sesuai dengan teori respon imun, bahwa IgM dengue akan muncul mulai hari ke-4 dan lambat laun akan menurun. IgG akan muncul pada infeksi primer dan terus meningkat setelah hari ke-5. Respon imun humoral maupun seluler yang berupa anti netralisasi, anti-hemaglutinasi dan anti komplemen terjadi setelah virus dengue berkembang biak dalam sel retikuloendotelial dan berada dalam darah (viremia) yang berlangsung 5 hingga 7 hari. Manifestasi yang bisa dideteksi pada tingkat laboratorium adalah IgM dan IgG. IgM dikenal sebagai antibodi fase akut, IgG dibedakan antara infeksi primer dan sekunder. Pada infeksi sekunder IgG meningkat sekitar demam hari ke-14. Hasil penelitian yang dilakukan oleh Changal KH, Raina AH, Raina A, et al., 2016, dengue dengan marker NS1 dan PCR adalah terbaik ditemukan pada fase awal infeksi dengue dan kemuadian baru IgM. Rasio IgG/IgM > 1,10 dengan sensitivitas $100 \%$, spesifisitas $97,4 \%$, dan 
akurasi $67,5 \%$ dalam membedakan infeksi dengue sekunder terhadap infeksi dengue primer. Dengue sekunder menyebabkan penyakit yang lebih parah dibandingkan dengue primer.

\section{KESIMPULAN}

Dari hasil penelitian dapat disimpulkan bahwa tidak semua suspek dengue di RS Roemani didapatkan NS1 positif, $16,6 \%$ pada gejala demam 0-2 hari, 3,3\% pada gejala demam 2-4 hari, dan $0 \%$ pada gejala demam 5-7 hari.

\section{DAFTAR PUSTAKA}

Ambrose JH, Sekaran SD, and Azizan A. 2017. Dengue Virus NS1 Protein as a Diagnostic Marker: Commercially Available ELISA and Comparison to qRT-PCR and Serological Diagnostic Assays Currently Used by the State of Florida. HindawiJournal of Tropical Medicine., Article ID 8072491, 6 pageshttps://doi.org/10.1155/2017/8 072491

Chandra A.2010. Dengue Hemorrhagic Fever: Epidemiology, Pathogenesis, and Its Transmission Risk Factors. Aspirator. 2(2):110-9

Changal KH, Raina AH, Raina A, et al. 2016. Differentiating secondary from primary dengue using IgG to IgM ratio in early dengue: an observational hospital based clinico-serological study from North India. BMC Infect Dis.16(1):715. Published 2016 Nov 28. doi:10.1186/s12879-016-20536

Dinkesprov Jawa Timur. (2017). Profil kesehatan Provinsi Jawa Timur tahun 2016. Dinas Kesehatan Provinsi Jawa Timur. Kota Surabaya.

Hadinegoro, Rezeki S, Soegianto S, Soeroso T, Waryadi S. 2001. Tata
Laksana Demam Berdarah Dengue di Indonesia. Jakarta: Ditjen PPM\&PL Depkes\&Kesos R.I

Mariko MR, Alkamar A, Putra AE. 2014. Uji Diagnostik Pemeriksaan Antigen Nonstruktural 1 untuk Deteksi Dini Infeksi Virus Dengue pada Anak. Sari Pediatri. 16 (2):121-7

Numinha, Sri N. 2012. Hubungan Jenis Infeksi dengan Derajat Keparahan pada Penderit Infeksi Virus Dengue di Rumah Sakit Kota Bandar Lampung. Jurnal Jurusan Analis Kesehatan. Vol. 1

Paranavitane SA, Gomes L, Kamaladasa A, Adikari TN, Wickramasinghe N, Jeewandara C, Shyamali NL, Ogg GS, Malavige GN. 2014. Dengue NS1 antigen as a marker of severe clinical disease. BMC Infect Dis.31(14):570. doi: 10.1186/s12879-014-0570

Peeling, Rosanna W, Harvey A, Jose LP, Philippe B, Mary JC, dkk. 2010. Evaluation of diagnostic tests: dengue. Unicef. 530-530

Perdigão AC, Ramalho IL, Guedes MI, et al. 2016. Coinfection with influenza $\mathrm{A}(\mathrm{H} 1 \mathrm{N1}) \mathrm{pdm} 09$ and dengue virus in fatal cases. Mem Inst Oswaldo Cruz. 111(9):588-591.

Pusat Data dan Informasi Kementerian Kesehatan RI.2017. Studi Oenyakit Demam Berdarah di Indonesia. ISSN 2442-7659

Rubens Costa Lima $\mathbf{J}^{1}$, Rouquayrol MZ, Monteiro Callado MR, Florindo Guedes MI, Pessoa C. 2012. Interpretation of the presence of IgM and $\mathrm{IgG}$ antibodies in a rapid test for dengue: analysis of dengue antibody prevalence in Fortaleza City in the 20th year of the epidemic. Rev Soc Bras Med Trop. 45(2):163-7.

Trisnadewi NL, Wande N. 2016. Pola Serologi Igm Dan Igg Pada Infeksi Demam Berdarah Dengue (Dbd) Di 
Rumah Sakit Umum Pusat Sanglah, Denpasar, Bali Bulan Agustus Sampai September 2014. E-Jurnal Medika. 5 (8):1-5
WHO. 2003. Pencegahan dan Penanggulangan Penyakit Demam Dengue dan Demam Berdarah Dengue. Jakarta: WHO \& Departemen Kesehatan RI. 
Tabel 1. Distribusi frekwensi NS1 berdasarkan suspek infeksi dengue

\begin{tabular}{ccccccc}
\hline & \multicolumn{3}{c}{ Suspek Infeksi Dengue } & \multicolumn{3}{c}{ Marker NS1 } \\
\hline \multirow{2}{*}{$\begin{array}{c}\text { Demam } \\
\text { (hari) }\end{array}$} & \multicolumn{2}{c}{ Rumple leed } & \multicolumn{2}{c}{ Positif } & \multicolumn{2}{c}{ Negatif } \\
\cline { 2 - 8 } & positif & Negative & Jumlah & $\%$ & Jumlah & $\%$ \\
\hline $0-2$ & 3 & 11 & 5 & 16,6 & 9 & 30 \\
\hline $3-4$ & 1 & 14 & 1 & 3,3 & 14 & 46.6 \\
\hline $5-7$ & 0 & 1 & 0 & 0 & 1 & 3,3 \\
\hline Jumlah & 4 & 26 & 6 & 20 & 24 & 80 \\
\hline
\end{tabular}

